\title{
Clostridium herbivorans sp. nov., a Cellulolytic Anaerobe from the Pig Intestine
}

\author{
VINCENT H. VAREL, ${ }^{1 *}$ RALPH S. TANNER, ${ }^{2}$ AND CARL R. WOESE ${ }^{3}$ \\ Roman L. Hruska U. S. Meat Animal Research Center, Agricultural Research Service, U. S. Department of Agriculture, \\ Clay Center, Nebraska 68933'; Department of Botany and Microbiology, University of Oklahoma, Norman, Oklahoma \\ $73019^{2}$; and Department of Microbiology, University of Illinois at Urbana-Champaign, Urbana, Illinois $61801^{3}$
}

\begin{abstract}
A new cellulolytic anaerobic clostridium was isolated from the intestinal tract of pigs. The single isolate was a gram-positive, motile rod, formed terminal to subterminal swollen sporangia, and required a fermentable carbohydrate for growth. Cellulose, cellobiose, maltose, starch, and glycogen supported growth, but glucose and fructose did not. The major end products from the fermentation of cellobiose were butyrate and formate; minor amounts of hydrogen and ethanol were also formed. Ruminal fluid (15\%) or yeast extract $(1 \%)$ was required for good growth. The optimum temperature for growth was 39 to $42^{\circ} \mathrm{C}$, and the optimum pH was 6.8 to 7.2. Cell lysis occurred rapidly once stationary growth was reached. A 16S rRNA sequence analysis showed that the strain was related to a group of gram-positive anaerobes that includes Clostridium oroticum and the cellulolytic species Clostridium polysaccharolyticum and Clostridium populeti. The DNA base composition of the isolate is $38 \mathrm{~mol} \% \mathrm{G}+\mathrm{C}$. We propose the name Clostridium herbivorans for this organism; strain 54408 (= ATCC 49925) is the type strain.
\end{abstract}

The most probable numbers for the cellulolytic bacterial population in the large intestines of pigs were estimated to be 4 and $6 \%$ of the viable bacterial counts when the animals were fed low- and high-fiber diets, respectively (33). Thus, significant quantities of cellulose may be degraded in the large intestines of pigs. The volatile fatty acids produced from this degradation are absorbed by the animals and influence the energy requirements of the animals. Our understanding of the cellulolytic bacterial species that make up this population is incomplete.

The anaerobic cellulolytic bacteria that have been isolated from pig intestinal tracts include Fibrobacter intestinalis (Fibrobacter succinogenes) $(18,33)$, Ruminococcus flavefaciens (33), and an unidentified clostridial species (34). The Clostridium species was isolated initially from pig intestinal tracts when the ruminal cellulolytic species "Clostridium longisporum" (32) was fed to pigs in an effort to ascertain whether this organism can colonize the pig intestinal tract (34). In this report we provide additional characteristics of the pig intestinal clostridium and propose the name Clostridium herbivorans.

\section{MATERIALS AND METHODS}

The cellulolytic clostridium described in this paper was isolated from pig intestinal contents by a procedure described previously (34). This isolate was named $C$. herbivorans, was designated strain $54408^{\mathrm{T}}(\mathrm{T}=$ type strain), and was deposited in the American Type Culture Collection as strain ATCC $49925^{\mathrm{T}}$.

Biochemical characterization. Phenotypic characteristics of strain $54408^{\mathrm{T}}$ were determined previously (34) and in this study. The media used for growth and characterization experiments were prepared under $\mathrm{CO}_{2}$ by the Hungate anaerobic culturing method described by Bryant (2) or by the methods described by Balch and Wolfe (1). Biochemical tests were performed by using the standard procedures described by Holdeman et al. (9) and Smibert and Krieg (27).

The medium used for routine growth of the culture contained (per $100 \mathrm{ml}$ ) 15 $\mathrm{ml}$ of clarified preincubated ruminal fluid, $0.3 \mathrm{~g}$ of cellobiose, $0.2 \mathrm{~g}$ of Trypticase (BBL Microbiology Systems, Cockeysville, Md.), $0.1 \mathrm{~g}$ of yeast extract, $0.04 \mathrm{~g}$ of $\mathrm{NH}_{4} \mathrm{Cl}, 5 \mathrm{ml}$ of mineral S2 (25), $0.5 \mathrm{ml}$ of vitamins (32), $0.0001 \mathrm{~g}$ of resazurin, 0.4 $\mathrm{g}$ of $\mathrm{Na}_{2} \mathrm{CO}_{3}$, and $0.05 \mathrm{~g}$ of cysteine hydrochloride. Good growth could be expected if the ruminal fluid was deleted and the concentration of yeast extract was increased to $1 \%(\mathrm{wt} / \mathrm{vol})$.

The optimum $\mathrm{pH}$ was determined with the medium described above, except \footnotetext{
4148.

* Corresponding author. Phone: (402) 762-4207. Fax: (402) 762-
}

that the $\mathrm{Na}_{2} \mathrm{CO}_{3}$ and $\mathrm{CO}_{2}$ atmosphere were replaced with phosphate buffer and an $\mathrm{N}_{2}$ atmosphere. In a second set of experiments we used the buffers PIPES (piperazine- $N, N^{\prime}$-bis-2-ethanesulfonic acid) and HEPES ( $N$-2-hydroxyethylpiperazine- $N$-2-ethanesulfonic acid) (Sigma Chemical Co., St. Louis, Mo.) in the medium described above, and the concentrations of $\mathrm{Na}_{2} \mathrm{CO}_{3}$ and $\mathrm{CO}_{2}$ were reduced to $0.04 \mathrm{~g} / 100 \mathrm{ml}$ and $10 \%$, respectively; an $\mathrm{N}_{2}$ atmosphere was used in these experiments. The PIPES-HEPES buffer system allowed the culture to grow better; however, the optimum $\mathrm{pH}$ for growth was the same as the optimum $\mathrm{pH}$ obtained with the phosphate buffer. $\mathrm{CO}_{2}$ appeared to stimulate growth

Microscopy. A culture of strain $54408^{\frac{7}{7}}$ was cooled on ice and fixed for $15 \mathrm{~min}$ with glutaraldehyde at a final concentration of $0.5 \%$. The fixed cells were allowed to settle onto carbon-coated Formvar films on copper grids and were stained with $1 \%$ phosphotungstate ( $\mathrm{pH} 7)$. Cellular morphology was determined with a Zeiss model EM-10 transmission electron microscope.

Cellular fatty acid analysis. The cellular fatty acid compositions of strain $54408^{\mathrm{T}}$ and Clostridium polysaccharolyticum ATCC $33142^{\mathrm{T}}$ were determined with cells grown on a cellobiose-yeast extract medium and harvested while they were in exponential growth phase. A cellular fatty acid analysis was performed by Microcheck, Inc. (Northfield, Vt.). Whole-cell fatty acids were analyzed as fatty acid methyl esters with a MIDI microbial identification system (MIDI, Inc., Newark, Del.). Fatty acid methyl esters were synthesized and analyzed as described previously $(17,20,26)$.

16S rRNA sequence analysis. Strain $54408^{\mathrm{T}}$ was grown on a cellobiose-yeast extract medium and harvested in the exponential growth phase. Clostridium oroticum ATCC $13619^{\mathrm{T}}$ and Clostridium symbiosum ATCC $14940^{\mathrm{T}}$ were provided by John L. Johnson, and Eubacterium eligens ATCC $27750^{\mathrm{T}}$ and Eubacterium ventriosum ATCC $27560^{\mathrm{T}}$ were provided by Robert $\mathrm{L}$. Gherna. The $16 \mathrm{~S}$ rRNAs of these strains were sequenced by using previously described methods $(15,22)$. The sequences of the other Clostridium and Eubacterium species used in this study have been published previously $(4,16,23,24,35)$. The sequences were analyzed by using a maximum-likelihood method (21)

Nucleotide sequence accession numbers. The 16S rRNA sequences of strain $54408^{\mathrm{T}}\left(C\right.$. herbivorans ATCC $\left.49925^{\mathrm{T}}\right)$, C. oroticum, C. symbiosum, E. eligens, and $E$. ventriosum have been deposited in GenBank database under accession numbers L34418, M59109, M59112, L394420, and L34421, respectively.

\section{RESULTS AND DISCUSSION}

Colony and cellular morphology. Electron microscopy and phase-contrast microscopy showed that cells of strain $54408^{\mathrm{T}}$ were motile, straight rods $(0.7$ to 0.9 by 3.5 to $4.0 \mu \mathrm{m})$ that occurred in pairs or as single cells (Fig. 1) (34). The cells were peritrichous, and cells from exponential-phase cultures frequently had 15 to 20 flagella per cell. Spores were rarely observed; however, when spores were present, they were subterminal to terminal and $1 \mu \mathrm{m}$ wide by 1 to $2 \mu \mathrm{m}$ long and caused swelling of the cells. When strain $54408^{\mathrm{T}}$ was grown in cellulose roll tubes, it produced two zones of clearing (Fig. 2), depend- 


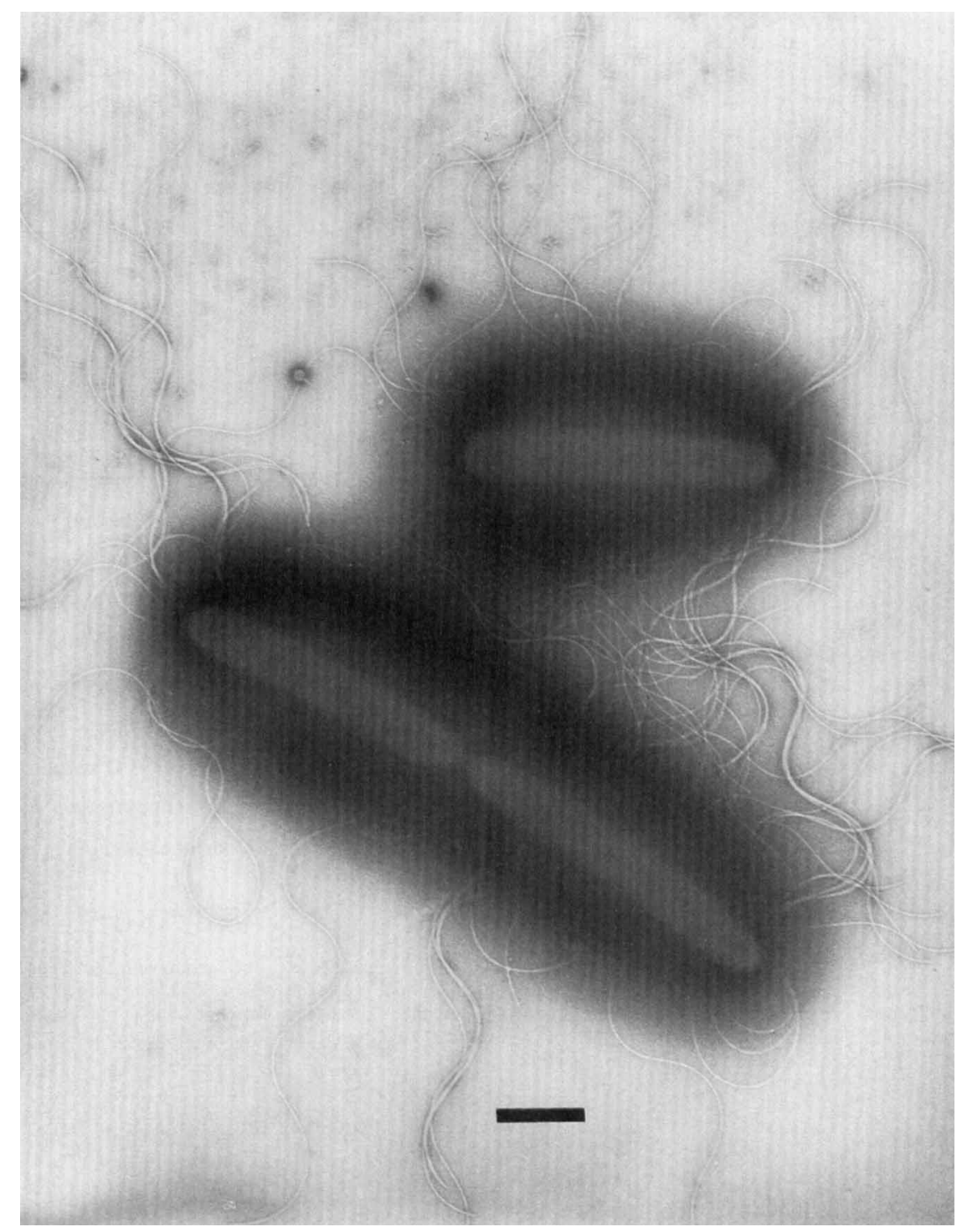

FIG. 1. Transmission electron micrograph of $C$. herbivorans. Cells were fixed with glutaraldehyde, spread on a carbon-coated Formvar grid, and stained with $1 \%$ phosphotungstic acid ( $\mathrm{pH} 7$ ). Bar $=1 \mu \mathrm{m}$.

ing on the location of the organism in the agar. If cells were on the surface of the agar, no visible colonies were formed and the zone of clearing was larger than the zone of clearing produced when cells were embedded in the agar. When cells were imbedded in the agar distinct colonies were produced.

Biochemical reactions. Growth of strain $54408^{\mathrm{T}}$ was supported by cellulose, cellobiose, maltose, starch, and glycogen. In the presence of cellobiose plus yeast extract the generation time was $2.3 \mathrm{~h}$ at $37^{\circ} \mathrm{C}$. Strain $54408^{\mathrm{T}}$ did not utilize substrates such as glucose, Casamino Acids, fructose, pectin, sucrose, xylose, and xylan. Other substrates that did not support growth were amygdalin, arabinose, erythritol, galactose, inositol, lactose, lactate, mannitol, mannose, melezitose, melibiose, pyruvate, raffinose, rhammose, ribose, sorbitol, and trehalose. Strain $54408^{\mathrm{T}}$ did not digest chopped meat or reduce sulfate or nitrate and was negative for catalase, oxidase, and urease activities. It produced formate $(28 \mathrm{mM})$ and butyrate $(12 \mathrm{mM})$ as major fermentation products when cells were cultured with cellobiose. Ethanol $(1 \mathrm{mM})$ and hydrogen $(5 \mathrm{mM})$ were also produced. Anaerobic conditions were required for growth. The optimum temperature for growth was between 39 and $42^{\circ} \mathrm{C}$; however, cultures could be adapted to grow at $45^{\circ} \mathrm{C}$. Growth did not occur at 25 or $55^{\circ} \mathrm{C}$. The optimum pH for growth was between 6.8 and 7.2. No growth occurred at $\mathrm{pH} 5.8$ or 8.0 . We have isolated other strains of this organism, including some strains isolated from Meishan pigs imported from the People's Republic of China. The characteristics of two strains which were obtained from Meishan pigs and which were characterized phenotypically were similar to the characteristics of type strain 54408 (34).

Cellular fatty acid composition. The cellular fatty acid composition of strain $54408^{\mathrm{T}}$ was distinct and was not similar to the cellular fatty acid composition of any other bacterium in the gram-positive low-G+C-content phylogenetic cluster (clostridia and clostridium-like organisms) $(4,29)$ in the MIDI database. The major components identified in strain $54408^{\mathrm{T}}$ were $\mathrm{C}_{14: 0}\left(43.8 \%\right.$ of the total fatty acids), iso-3-OH $\mathrm{C}_{13: 0}(8.9 \%)$, $\mathrm{C}_{16: 0}(5.3 \%)$, iso $\mathrm{C}_{14: 0}(2.2 \%)$, cis-9 $\mathrm{C}_{18: 1}(1.4 \%), \mathrm{C}_{14: 0}$ di- 


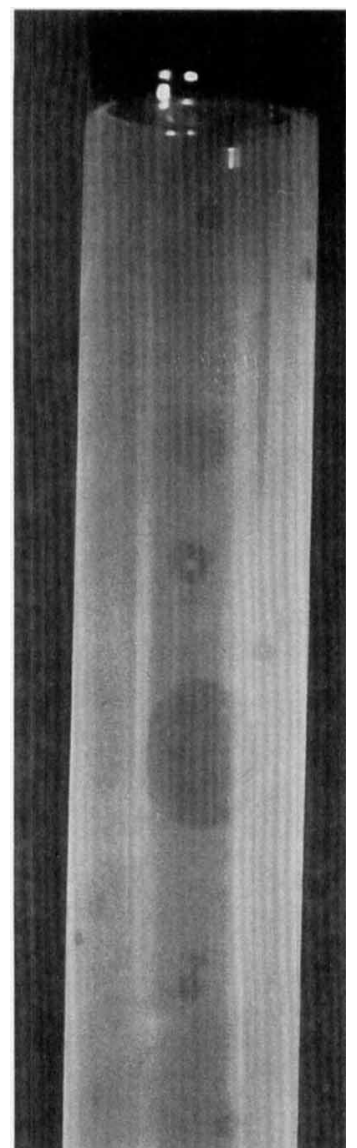

FIG. 2. Zones of clearing produced by $C$. herbivorans after $48 \mathrm{~h}$ in an agar roll tube (18 by $150 \mathrm{~mm}$ ) with ball-milled filter paper as the substrate. A large zone of clearing without a colony was formed when cells were on the surface of the agar. Cells embedded in the agar produced a smaller zone of clearing with a visible colony.

methyl acetal $(22.1 \%)$ and $\mathrm{C}_{14: 0}$ aldehyde $(10.2 \%)$. The presence of the two latter components indicated that plasmalogen was present in the cells (11). C. polysaccharolyticum was phylogenetically related to strain $54408^{\mathrm{T}}$ (see below) and was analyzed to determine its fatty acid composition since it was not included in the MIDI database. The cellular fatty acid profile of this organism was distinct from that of strain $54408^{\mathrm{T}}$. The major components identified in $C$. polysaccharolyticum were iso-3-OH $\mathrm{C}_{13: 0}\left(24.9 \%\right.$ of the total fatty acids), $\mathrm{C}_{14: 0}$ (22.1\%), iso $\mathrm{C}_{14: 0}(11.9 \%), \mathrm{C}_{16: 0}(5.9 \%), \mathrm{C}_{15: 0}(5.8 \%)$, anteiso $\mathrm{C}_{15: 0}(2.9 \%)$, iso $\mathrm{C}_{16: 0}(2.2 \%), \mathrm{C}_{14: 0}$ diamethyl acetal (8.8\%), $\mathrm{C}_{15: 0}$ anteiso dimethyl acetal $(5.1 \%)$, and $\mathrm{C}_{14: 0}$ aldehyde $(3.4 \%)$. The presence of the three latter components also indicated that plasmalogen is present in $C$. polysaccharolyticum.

Phylogeny. Figure 3 shows the phylogenetic relationship of strain $54408^{\mathrm{T}}$ to other clostridia and related microorganisms, including several mesophilic, cellulolytic species (Table 1). This phylogenetic tree, which was prepared by using a maximum-likelihood method (21), is essentially identical topographically to the tree prepared with a distance matrix method $(5,13,22)$ previously used by us (data not shown).

Strain $54408^{\mathrm{T}}$ was more closely related to $C$. polysaccharolyticum than to any of the other species whose sequences were deposited in the rRNA database (16). However, the 16S rRNA sequences of strain $54408^{\mathrm{T}}$ and $C$. polysaccharolyticum differ by

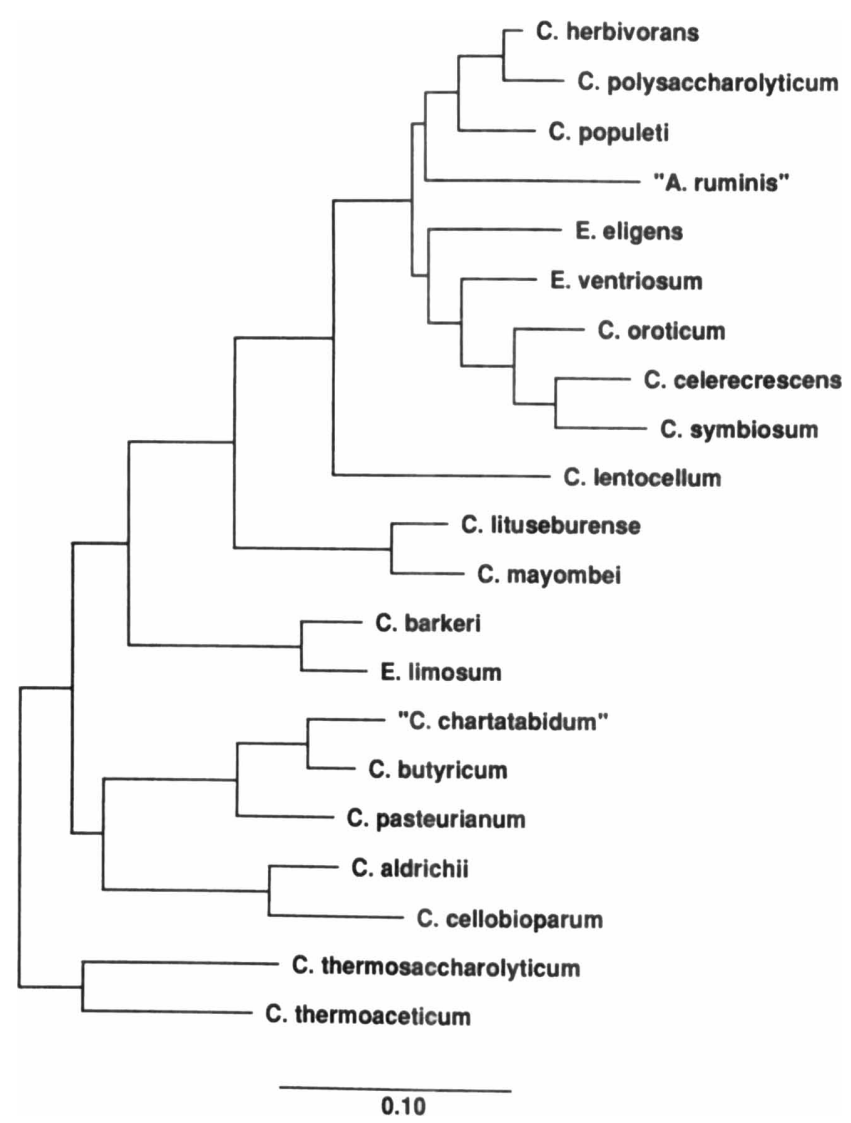

FIG. 3. Phylogeny of $C$. herbivorans $54408^{\mathrm{T}}$ as determined from a maximumlikelihood (21) 16S rRNA sequence analysis. The bar indicates the average number of base changes per position in the sequences compared. C., Clostridium; A., "Acetitomaculum"; and E., Eubacterium.

$3.3 \%$, indicating that these organisms belong to different species (28).

Strain $54408^{\mathrm{T}}$ is a member of a group of clostridia, designated cluster XIVa by Collins et al. (4), which includes "Acetitomaculum ruminis" (6), Clostridium celerecrescens, C. oroticum, Clostridium populeti, C. symbiosum, E. eligens (10), and E. ventriosum. This group of clostridia is phylogenetically distinct from clostridial rRNA homology group I defined by Johnson and Francis (12), which was called cluster I by Collins et al. (4), was represented in this study by Clostridium butyricum, "Clostridium chartatabidum," and Clostridium pasteurianum, and also includes the cellulolytic species Clostridium cellulovorans and "Clostridium longisporum." Clostridial rRNA homology group II of Johnson and Francis (12), which was designated cluster cluster XI by Collins et al. (4), is represented in Fig. 3 by Clostridium lituseburense and Clostridium mayombei. The phylogeny of the other cellulolytic clostridia has been discussed by Collins et al. (4) and was specifically examined by Rainey and Stackebrandt $(24)$. Strain $54408^{\mathrm{T}}$ is phylogenetically distinct from the other mesophilic, cellulolytic clostridia.

Distinguishing characteristics. Some of the characteristics which distinguish $C$. herbivorans from phylogenetically related species and the mesophilic cellulolytic clostridia are listed in Table 1 . The closest relative, phylogenetically and phenotypically, of $C$. herbivorans is $C$. polysaccharolyticum. Both species utilize cellulose, cellobiose, maltose, and starch, although they do not utilize glucose. The distinguishing characteristics include $\mathrm{G}+\mathrm{C}$ content ( 38 and $42 \mathrm{~mol} \%$ ) and the fermentation of 
TABLE 1. Characteristics that differentiate $C$. herbivorans from phylogenetically related bacteria and the mesophilic cellulolytic clostridia

\begin{tabular}{|c|c|c|c|c|c|c|c|c|c|c|c|c|c|}
\hline \multirow{2}{*}{ Organism $^{a}$} & \multirow{2}{*}{$\begin{array}{c}\mathrm{G}+\mathrm{C} \\
\text { content } \\
(\mathrm{mol} \%)\end{array}$} & \multirow{2}{*}{$\begin{array}{c}\text { End } \\
\text { products }^{b}\end{array}$} & \multirow{2}{*}{ Motility } & \multicolumn{10}{|c|}{ Fermentation of : } \\
\hline & & & & Arabinose & Glucose & Cellobiose & Cellulose & Fructose & Galactose & Maltose & Starch & Xylose & Xylan \\
\hline C. herbivorans & 38 & $\mathrm{~F}, \mathrm{~B}, \mathrm{e}$ & + & - & - & + & + & - & - & + & + & - & - \\
\hline C. polysaccharolyticum & 42 & $\mathrm{~F}, \mathrm{~B}, \mathrm{e}$ & + & + & - & + & + & $+1-$ & - & + & + & + & + \\
\hline C. aldrichii & 40 & $\mathrm{~A}, \mathrm{P}, \mathrm{B}, \mathrm{L}, \mathrm{S}$ & + & - & - & + & + & - & NR & - & - & - & t \\
\hline C. celerecrescens & 38 & $\mathrm{~A}, \mathrm{E}, \mathrm{F}, \mathrm{B}, \mathrm{L}, \mathrm{S}$ & + & + & + & + & + & + & + & + & - & + & NR \\
\hline C. cellobioparum & 28 & $\mathrm{~A}, \mathrm{E}, \mathrm{l}, \mathrm{f}$ & + & + & + & + & + & + & + & + & - & + & NR \\
\hline C. cellulofermentans & 34 & $\mathrm{~A}, \mathrm{E}$ & + & - & + & + & + & + & + & + & - & + & NR \\
\hline C. cellulolyticum & 41 & $\mathrm{~A}, \mathrm{E}, \mathrm{l}, \mathrm{f}$ & + & + & + & + & + & + & W & - & - & + & NR \\
\hline C. cellulovorans & 27 & $\mathrm{~B}, \mathrm{a}, \mathrm{f}$ & - & - & + & + & + & + & + & + & - & - & + \\
\hline "C. chartatabidum" & 31 & $\mathrm{~A}, \mathrm{~B}, \mathrm{E}$ & + & NR & + & + & + & + & - & - & - & + & - \\
\hline C. josui & 40 & $\mathrm{~A}, \mathrm{E}, \mathrm{p}, \mathrm{b}$ & - & + & + & + & + & - & - & + & - & + & + \\
\hline C. lentocellum & 36 & A,E,I & + & + & + & + & + & + & + & + & + & + & + \\
\hline "C. longisporum" & 33 & $\mathrm{~F}, \mathrm{~A}, \mathrm{~B}, \mathrm{e}$ & + & - & + & + & + & + & + & - & - & - & - \\
\hline C. papyrosolvens & 30 & $\mathrm{~A}, \mathrm{~L}, \mathrm{E}$ & + & + & + & + & + & + & + & - & NR & + & NR \\
\hline C. populeti & 28 & $\mathrm{~B}, \mathrm{a}, \mathrm{l}$ & + & + & + & + & + & + & + & + & - & + & + \\
\hline C. termitidis & 39 & $\mathrm{~A}, \mathrm{E}$ & + & - & + & + & + & + & + & + & - & + & NR \\
\hline C. oroticum ${ }^{d}$ & 44 & $\mathrm{~A}, \mathrm{E}, 1, \mathrm{f}$ & - & $+1-$ & + & $+1-$ & - & + & NR & + & - & + & NR \\
\hline C. symbiosum ${ }^{e}$ & 46 & A,B & - & + & + & - & - & + & + & - & - & + & NR \\
\hline E. ventriosumf & NR & $\mathrm{F}, \mathrm{b}, \mathrm{l}, \mathrm{a}$ & - & $+1-$ & + & $+1-$ & - & + & + & + & + & $+1-$ & NR \\
\hline
\end{tabular}

${ }^{a}$ See reference 7 and the references cited in reference 7 for other characteristics.

${ }^{b} \mathrm{~F}$ and $\mathrm{f}$, formate; $\mathrm{A}$ and $\mathrm{a}$, acetate; $\mathrm{P}$ and $\mathrm{p}$, propionate; $\mathrm{B}$ and $\mathrm{b}$, butyrate; $\mathrm{L}$ and $\mathrm{l}$, lactate; $\mathrm{S}$, succinate; $\mathrm{E}$ and $\mathrm{e}$, ethanol. Uppercase letters indicate major end products, and lowercase letters indicate minor end products.

$c+$, positive; - , negative; $+/-$, weak or some strains are positive while others are negative; NR, not reported.

${ }^{d}$ See references 3,8 , and 9 .

$e$ See references 3 and 14

${ }^{f}$ See reference 19 .

arabinose, xylan, and xylose by $C$. polysaccharolyticum but not by $C$. herbivorans. The ecosystems from which these organisms were isolated (pig intestinal tracts and sheep rumina for $C$. herbivorans and C. polysaccharolyticum, respectively) are also different. The cell morphologies and peritrichous flagella of these two species are similar, and both organisms are straight rods that occur singly or in pairs. $C$. polysaccharolyticum is typically $0.8 \mu \mathrm{m}$ wide by 3 to $6 \mu \mathrm{m}$ long, while $C$. herbivorans is $0.8 \mu \mathrm{m}$ wide by $4.0 \mu \mathrm{m}$ long. Long chains and aseptate filaments that are $50 \mu \mathrm{m}$ or more long have been observed in C. polysaccharolyticum cultures $(30,31)$, but have not been seen in $C$. herbivorans cultures.

C. herbivorans can be distinguished from all of the remaining mesophilic cellulolytic and phylogenetically related organisms except Clostridium aldrichii by its lack of glucose fermentation. $C$. herbivorans and $C$. aldrichii can be clearly differentiated by their fermentation products and fermentation of glycogen, maltose, starch, and xylan. $C$. herbivorans is also distinct from all organisms listed in Table 1 except $C$. polysaccharolyticum in that it does not produce acetate.

Description of Clostridium herbivorans sp. nov. Clostridium herbivorans (her.bi.vo'rans.L. fem. n. herba, a green plant; L. v. voro, to devour; M. L. part. adj. herbivorans, devouring plants). Cells are gram-positive straight rods $(0.7$ to 0.9 by 3.5 to 4.0 $\mu \mathrm{m})$ that occur in pairs or as single cells. Cells are motile, and peritrichous with 15 to 20 flagella per cell. Cells rarely sporulate; however, when spores are present, they are subterminal to terminal and $1 \mu \mathrm{m}$ wide by $2 \mu \mathrm{m}$ long and cause the sporangium to swell. Cultures grown with insoluble substrates such as cellulose or plant cell walls more readily produce spores than do those grown with soluble substrates.

Obligate anaerobe. Growth requires a fermentable carbohydrate such as cellobiose, cellulose, maltose, starch, or glycogen. The following compounds do not support growth: amygdalin, arabinose, Casamino Acids, erythritol, fructose, glucose, inositol, lactate, lactose, mannitol, mannose, melezitose, melibiose, pectin, pyruvate, raffinose, rhammose, ribose, salicin, sorbitol, sucrose, trehalose, xylose, and xylan. Nitrate and sulfate are not reduced. Catalase, oxidase, and urease negative. Esculin, lecithin, and gelatin are not hydrolyzed. Meat is not digested. Indole is not produced.

The optimum temperature for growth is 39 to $42^{\circ} \mathrm{C}$, and the optimum $\mathrm{pH}$ for growth is 6.8 to 7.2. Rapid lysis of cells occurs in broth media once the stationary growth phase is reached; this is slightly less true with agar media. Ruminal fluid $(15 \%$, $\mathrm{vol} / \mathrm{vol})$ and yeast extract $(1 \%$, wt/vol) stimulate growth.

The major end products of cellobiose fermentation are formate and butyrate; minor amounts of ethanol and hydrogen are also produced.

The $\mathrm{G}+\mathrm{C}$ content of the DNA is $38 \mathrm{~mol} \%$ (as determined by the buoyant density method).

The type strain, strain 54408, was isolated from intestinal contents of a pig and has been deposited in the American Type Culture Collection as strain ATCC 49925.

\section{ACKNOWLEDGMENTS}

We thank Greg Strout (Samuel Roberts Noble Electron Microscopy Laboratory) for assistance with the electron microscopy. We thank John L. Johnson and Robert $\mathrm{L}$. Gherna for providing $C$. oroticum, $C$. symbiosum, E. eligens, and E. ventriosum and Linda Mandelco for sequencing the rRNAs of these organisms. The technical assistance of Phil Anderson and Gina Rolls and typing by Jan Watts are appreciated. We also thank Wilson Pond for encouragement and helpful discussions which led to the isolation of strain $54408^{\mathrm{T}}$.

The work of C. R. Woese was supported by grant BSR-87-05352 from the National Science Foundation.

\section{REFERENCES}

1. Balch, W. E., and R. S. Wolfe. 1976. New approach to the cultivation of methanogenic bacteria: 2-mercaptoethanesulfonic acid (HS-CoM)-dependent growth of Methanobacterium numinantium in a pressurized atmosphere. Appl. Environ. Microbiol. 32:781-791.

2. Bryant, M. P. 1972. Commentary on the Hungate technique for culture of 
anaerobic bacteria. Am. J. Clin. Nutr. 25:1324-1328.

3. Cato, E. P., W. L. George, and S. M. Finegold. 1986. Clostridium, p. 1141 1200. In P. H. A. Sneath, N. S. Mair, M. E. Sharpe, and J. G. Holt (ed.) Bergey's manual of systematic bacteriology, vol. 2. Williams \& Wilkins, Baltimore.

4. Collins, M. D., P. A. Lawson, A. Willems, J. J. Cordoba, J. FernandezGarayzabal, P. Garcia, J. Cai, H. Hippe, and J. A. E. Farrow. 1994. The phylogeny of the genus Clostridium: proposal of five new genera and eleven new species combinations. Int. J. Syst. Bacteriol. 44:812-826.

5. De Soete, G. 1983. A least squares algorithm for fitting additive trees to proximity data. Psychometrika 48:621-626.

6. Greening, R. C., and J. A. Z. Leedle. 1989. Enrichment and isolation of Acetitomaculum ruminis, gen. nov., sp. nov.: acetogenic bacteria from the bovine rumen. Arch. Microbiol. 151:399-406.

7. Hethener, P., A. Brauman, and J. L. Garcia. 1992. Clostridium termitidis sp. nov., a cellulolytic bacterium from the gut of the wood-feeding termite, Nasulitermes lujae. Syst. Appl. Microbiol. 15:52-58.

8. Hippe, H., J. R. Andreesen, and G. Gottschalk. 1992. The genus Clostridium-nonmedical, p. 1800-1866. In A. Balows, H. G. Trüper, M. Dworkin W. Harder, and K.-H. Schleifer (ed.), The prokaryotes, vol. 2, 2nd ed. Springer-Verlag, New York.

9. Holdeman, L. V., E. P. Cato, and W. E. C. Moore (ed.). 1977. Anaerobe laboratory manual, 4th ed. Virginia Polytechnic Institute and State University, Blacksburg.

10. Holdeman, L. V., and W. E. C. Moore. 1974. New genus, Coprococcus, twelve new species, and emended descriptions of four previously described species of bacteria from human feces. Int. J. Syst. Bacteriol. 24:260-277.

11. Jantzen, E., and T. Hofstad. 1981. Fatty acids of Fusobacterium species: taxonomic implications. J. Gen. Microbiol. 123:163-171.

12. Johnson, J. L., and B. S. Francis. 1975. Taxonomy of the clostridia: ribosomal ribonucleic acid homologies among the species. J. Gen. Microbiol 88:229-244.

13. Jukes, T. H., and C. R. Cantor. 1969. Evolution of protein molecules, p 21-132. In H. N. Munro (ed.), Mammalian protein metabolism, vol. 3 . Academic Press, New York.

14. Kaneuchi, C., K. Watanabe, A. Terada, Y. Benno, and T. Mitsuoka. 1976 Taxonomic study of Bacteroides clostridiiformis subsp. clostridiiformis (Burr and Ankersmit) Holdeman and Moore and of related organisms: proposal of Clostridium clostridiuformis (Burri and Ankersmit) comb. nov. and Clostridium symbisoum (Stevens) comb. nov. Int. J. Syst. Bacteriol. 26:195-204.

15. Lane, D. J., B. Pace, G. J. Olsen, D. A. Stahl, M. L. Sogin, and N. R. Pace. 1985. Rapid determination of 16S ribosomal RNA sequences for phylogenetic analysis. Proc. Natl. Acad. Sci. USA 82:6955-6959.

16. Maidak, B. L., N. Larson, M. J. McCaughey, R. Overbeek, G. J. Olsen, K. Fogel, J. Blandy, and C. R. Woese. 1994. The Ribosomal Database Project. Nucleic Acids Res. 22:3485-3487.

17. Miller, L. T. 1982. Single derivitization method for routine analysis of bacterial whole-cell fatty acid methyl esters, including hydroxy acids. J. Clin. Microbiol. 16:584-586.

18. Montgomery, L., B. Flesher, and D. Stahl. 1988. Transfer of Bacteroides succinogenes (Hungate) to Fibrobacter gen. nov. as Fibrobacter succinogenes comb. nov. and description of Fibrobacter intestinalis sp. nov. Int. J. Syst. Bacteriol. 38:430-435.
19. Moore, W. E. C., and L. V. H. Moore. 1986. Eubacterium, p. 1353-1373. In P. H. A. Sneath, N. S. Mair, M. E. Sharpe, and J. G. Holt (ed.), Bergey's manual of systematic bacteriology, vol. 2. Williams \& Wilkins, Baltimore.

20. Moss, C. W., P. L. Wallace, D. G. Hollis, and R. E. Weaver. 1988. Cultural and chemical characterization of CDC groups EO-2, M-5, and M-6, Moraxella (Moraxella) species, Oligella urethralis, Acinetobacter species, and Psychrobacter immobilis. J. Clin. Microbiol. 26:484-492.

21. Olsen, G. J., H. Matsuda, R. Hagstrom, and R. Overbeek. 1994. FastDNAml: a tool for construction of phylogenetic trees of DNA sequences using maximum likelihood. Comput. Appl. Biosci. 10:41-48.

22. Ozaizu, H., B. Debrunner-Vossbrinck, L. Mandelco, J. A. Studier, and C. R. Woese. 1987. The green non-sulfur bacteria: a deep branching in the eubacterial line of descent. Syst. Appl. Microbiol. 9:47-53.

23. Paster, B. J. J. B. Russell, C. M. J. Yang, J. M. Chow, C. R. Woese, and R Tanner. 1993. Phylogeny of the ammonia-producing ruminal bacteria Peptostreptococcus anaerobius, Clostridium sticklandii, and Clostridium aminophilum sp. nov. Int. J. Syst. Bacteriol. 43:107-110.

24. Rainey, F. A., and E. Stackebrandt. 1993. 16S rDNA analysis reveals phylogenetic diversity among the polysaccharolytic clostridia. FEMS Microbiol. Lett. 113:125-128.

25. Salanitro, J. P., I. G. Fairchilds, and Y. D. Zgornicki. 1974. Isolation, culture characteristics, and identification of anaerobic bacteria from the chicken cecum. Appl. Microbiol. 27:678-687.

26. Sasser, M. 1990 . Identification of bacteria by gas chromatography of cellular fatty acids. MIDI Technical Note 101. MIDI, Inc., Newark, Del.

27. Smibert, R. M., and N. R. Krieg. 1994. Phenotypic characterization, p. 607-651. In P. Gerhardt, R. G. E. Murray, W. A. Wood, and N. R. Krieg (ed.), Methods for general and molecular bacteriology. American Society for Microbiology, Washington, D.C

28. Stackebrandt, E., and B. M. Goebel. 1994. Taxonomic note: a place for DNA-DNA reassociation and 16S rRNA sequence analysis in the present species definition in bacteriology. Int. J. Syst. Bacteriol. 44:846-849.

29. Tanner, R. S., and C. R. Woese. 1994. A phylogenetic assessment of the acetogens, p. 254-269. In H. L. Drake (ed.), Acetogenesis. Chapman \& Hall, New York.

30. Van Gylswyk, N. O. 1980. Fusobacterium polysaccharolyticum sp. nov., a Gram-negative rod from the rumen that produces butyrate and ferments cellulose and starch. J. Gen. Microbiol. 116:157-163.

31. Van Gylswyk, N. O., E. J. Morris, and H. J. Els. 1980. Sporulation and cell wall structure of Clostridium polysaccharolyticum comb. nov. (formerly Fu. sobacterium polysaccharolyticum). J. Gen. Microbiol, 121:491-493.

32. Varel, V. H. 1989. Reisolation and characterization of Clostridium longisporum, a ruminal sporeforming cellulolytic anaerobe. Arch. Microbiol. 152: 209-214.

33. Varel, V. H., S. J. Fryda, and I. M. Robinson. 1984. Cellulolytic bacteria from pig large intestine. Appl. Environ. Microbiol. 47:219-221.

34. Varel, V. H., and W. G. Pond. 1992. Characteristics of a new cellulolytic Clostridium sp. isolated from pig intestinal tract. Appl. Environ. Microbiol. 58:1645-1649.

35. Zhao, H., D. Yang, C. R. Woese, and M. P. Bryant. 1993. Assignment of fatty acid- $\beta$-oxidizing syntrophic bacteria to Syntrophomonadaceae fam. nov. on the basis of 16S rRNA sequence analyses. Int. J. Syst. Bacteriol. 43:278-286. 